\title{
THE PRIOR OBLIGATIONS OBJECTION TO THEOLOGICAL STATEISM
}

\author{
Frederick Choo
}

\begin{abstract}
Theological stateist theories, the most well-known of which is Divine Command Theory (DCT), ground our moral obligations directly in some state of God. The prior obligations objection poses a challenge to theological stateism. Is there a moral obligation to obey God's commands? If no, it is hard to see how God's commands can generate any moral obligations for us. If yes, then what grounds this prior obligation? To avoid circularity, the moral obligation must be grounded independent of God's commands; and therefore DCT fails to ground all moral obligations in God's commands. I argue that DCT proponents should embrace "metaethical DCT." On this view, there is no moral obligation to obey God. God creates our moral obligations out of normative nothingness. I argue that this helps DCT proponents to escape the prior obligations objection. Other theological stateist theories can modify their theory similarly to meet this objection.
\end{abstract}

\section{Introduction}

Theological stateism holds that our moral obligations are "directly, immediately, and entirely dependent upon some state of God, where divine willings, commands, desires, and other attitudes all count as states." ${ }^{1}$ The most well-known of version of theological stateism is Divine Command Theory (DCT), which says that our moral obligations are grounded in God's commands. ${ }^{2}$ In this paper, I defend theological stateism against a recent challenge known as the "prior obligations objection." To address the objection, I argue that DCT proponents should embrace what Mark Murphy calls "metaethical DCT." On this view, there is no moral obligation to obey God. God creates our moral obligations out of normative nothingness. I argue that this helps DCT proponents to escape the prior

\footnotetext{
${ }^{1}$ Wielenberg, Robust Ethics, 73.

${ }^{2}$ For discussion of other theological stateist theories, see Murphy, "Divine Command, Divine Will, and Moral Obligation"; Quinn, "Obligation, Divine Commands and Abraham's Dilemma"; Miller, "Divine Desire Theory and Obligation"; and Jordan, "Divine Commands or Divine Attitudes."
} 
obligations objection. Other theological stateist theories can modify their theory similarly to meet this objection.

\section{The Prior Obligations Objection}

Critics of DCT have posed the following dilemma for the view. ${ }^{3}$ Either

(1) There is no moral obligation to obey God's commands, or

(2) There is a moral obligation to obey God's commands.

Let us first suppose that a DCT proponent wants to affirm (1). Critics of DCT argue this is unacceptable. If there is no moral obligation to obey God's commands, how can DCT be true? After all, if there is no moral obligation to obey God's commands, how can God's commanding activity create any moral obligations for us? Why should we obey what God commands? The idea here is that if our moral obligations come from God's commands, then there must be a moral obligation to obey God in the first place, a "prior obligation" to obey God. Without appealing to the prior obligation, God's commands seem to lack normative authority and hence cannot be the source of our obligations. ${ }^{4}$ Call this problem the whyobey-God problem. Because of this problem, some critics of DCT do not even consider (1) a plausible option for DCT proponents. Ralph Cudworth, for example, says "[T] hat we should be obliged to obey ... must proceed from ... an antecedent obligation to obedience in the subjects." ${ }^{5}$ Similarly, Nicholas Wolterstorff says, "Commands are not the sort of thing that can generate obligations ex nihilo; they presuppose a normative context of prior obligations and rights." ${ }^{\prime 6}$ Wolterstorff thinks that in order for God's commanding to generate obligations, there must already exist a "standing obligation on our part to obey God by performing such actions as God may command," and this standing obligation cannot be generated from God's commands. ${ }^{7}$ So these critics think that DCT proponents must affirm (2) and cannot hold to (1).

Affirming (2) however results in two problems for the DCT proponent. First, (2) seems to entail that God's commanding is not the source of all moral obligations. ${ }^{8}$ This is because the moral obligation to obey God cannot come from God's commands itself, for this would be viciously circular. To see this, imagine your friend says that you are obligated to

${ }^{3}$ Forms of this argument have been raised by Mackie, The Miracle of Theism, 114-115; Cudworth, Treatise Concerning Eternal and Immutable Morality, Wolterstorff, Justice: Rights and Wrongs, 274-281; Forcehimes, "Ethical Theories and Their Application," 23-24; Fales, "Divine Commands and Moral Obligation," 156-157, Wielenberg, Robust Ethics, 53-55.

${ }^{4}$ Forcehimes, "Ethical Theories and Their Application," 24.

${ }^{5}$ Cudworth, Treatise Concerning Eternal and Immutable Morality, 18. See also Wielenberg (Robust Ethics, 54) who echoes this.

${ }^{6}$ Wolterstorff, Justice, 276.

${ }^{7}$ Wolterstorff, Justice, 277.

${ }^{8}$ Forcehimes, "Ethical Theories and Their Application," 24. 
obey her commands. When you ask why you are obligated to obey her commands, she says it is because she commanded you to obey her. This is explanatorily circular and thus unacceptable. If there is an obligation to obey your friend's commands, it has to be grounded independently of her commands. Likewise, if there is a prior obligation to obey God, it must be grounded independently of God's commands. Therefore, DCT fails to ground all our moral obligations in God's commands. ${ }^{9}$ Second, a DCT proponent who embraces (2) would plausibly hold the prior obligation as a brute fact, having no further explanation or grounding. If there is a brute moral obligation, then DCT would lose one of their explanatory advantages over non-theistic ethical theories which take a brute-facts approach. Erik Wielenberg, for example, defends a non-theistic ethical theory where ethical facts are substantive, metaphysically necessary, and brute. ${ }^{10}$ And he is not alone in holding such a view. A number of philosophers have embraced such a theory. DCT proponents have previously argued that DCT is better than such non-theistic ethical theories because DCT does more explanatory work by grounding our moral obligations in God. It is better to hold to a theory which says that morality has its foundation in God rather than having no foundation at all. Saying that morality has no foundation is problematic because the existence of moral obligations seems to cry out for an explanation. Non-natural moral obligations, which exist without explanation, are often thought of as queer or odd entities. Wielenberg himself however argues that theological stateist theories must posit brute ethical facts and hence are in the same boat as his own non-theistic ethical theories. ${ }^{11}$ If a DCT proponent embraces (2) and holds that (2) is simply a brute moral obligation, then DCT would lose one of its explanatory advantages. Just as DCT proponents have criticized non-theistic ethical theories for positing brute moral obligations, Wielenberg can criticize DCT by asking back, "what is the grounding for [the prior obligation]? Does it simply float mysteriously in an unintelligible way?"12 $\mathrm{He}$ can simply point out that "on both [Wieleneberg's theory and theological stateist theories], the bottom floor of objective morality rests ultimately on nothing." 13 Now of course the DCT proponent who embraces (2) might not hold the prior obligation as a brute fact. However, such a view still faces a similar problem, as we will see later.

The prior obligations objection applies to the other theological stateist theories in a similar way. In the objection above, we can simply substitute God's commands for God's will, attitudes and so forth. The same problem will then arise. So, the prior obligations objection is a challenge for the different theological stateist theories to meet.

\footnotetext{
${ }^{9}$ Forcehimes, "Ethical Theories and Their Application," 24.

${ }^{10}$ See Wielenberg, Robust Ethics.

${ }^{11}$ Wielenberg, Robust Ethics, 42-46, 50-56.

${ }^{12}$ Wielenberg, Robust Ethics, 53.

${ }^{13}$ Wielenberg, Robust Ethics, 55.
} 


\section{The Proving-Too-Much Reply and Normative Divine Command Theory}

Before advancing my own reply, I want to explore two replies that have been advanced by DCT proponents. The first reply is what I call the proving-too-much reply. Some DCT proponents have tried to show that the prior obligations objection would prove too much, as the objection would apply to all moral theories. Therefore, the objection cannot be right. Take, for example, social contract theory. Matthew Flannagan and Paul Copan say, "According to a social contract view, moral obligations are those requirements that rational, impartial persons in a society would agree to. But [those who advance the prior obligations objection] could argue that one is morally obligated to such a contract only if there is already an obligation to follow such hypothetical agreements. So, the hypothetical agreement can't itself be the source of moral obligations." ${ }^{14}$ C. Stephen Evans makes the same point with respect to Kantianism..$^{15}$ A Kantian says our moral obligations are those derived from the categorical imperative. But, once again, those who advance the prior obligations objection could argue that there must be a moral obligation to obey the categorical imperative in the first place. Therefore not all obligations come from the categorical imperative. So DCT proponents like Flannagan, Copan, and Evans claim that if this objection is successful, then all moral theories have a similar problem. This would however show too much. Hence, we should think something has gone wrong with the objection. To note, these DCT proponents are not alone. Even Mark Schroeder, who is not a DCT proponent, has argued along similar lines. ${ }^{16}$

The proving-too-much reply however does not seem satisfactory to me for a few reasons. First, the proving-too-much reply is effective only in some contexts. ${ }^{17}$ For example, when in dialogue with philosophers who are already committed to moral realism, the proving-too-much reply may succeed..$^{18}$ However, when in dialogue with philosophers not yet committed to moral realism, such a strategy may not always work. J. L. Mackie, for example, has raised the prior obligations objection and Mackie himself holds to an error theory of morality. Showing that the prior obligations objection would apply to all (realist) moral theories would not be a good reply to Mackie. After all, Mackie's arguments for an error theory of morality would similarly pose a problem for all (realist) moral theories. Yet, we do not think that we can simply dismiss Mackie's arguments by pointing out that his arguments would create a problem for all (realist) moral theories. In fact, Mackie might happily agree that the prior obligations objection applies to all (realist) moral theories and this would be

\footnotetext{
${ }^{14}$ Flannagan and Copan, Did God Really Command Genocide, 165-167.

${ }^{15}$ Evans, God and Moral Obligation, 100.

${ }^{16}$ Schroeder, "Cudworth and Normative Explanations."

${ }^{17}$ I thank Wayne Riggs for a discussion on this point.

${ }^{18}$ One reviewer has pointed out that expressivists who affirm that some actions are obligatory and there is an explanation for it may be in the same boat as moral realists.
} 
another argument in favor of his error theory. So, although the provingtoo-much reply may be effective when in dialogue with moral realists, it fails as a reply to those who do not share the same commitments as moral realists. ${ }^{19}$

Second, it is not clear that the prior obligations objection actually applies to all moral theories. For example, it seems that the objection cannot be applied to Wielenberg's theory, since Wielenberg already posits brute ethical facts that require no further explanation. So, it is simply not true that all moral theories face this objection.

Third, the proving-too-much reply does not directly address the dilemma. There is still a question of whether DCT proponents should embrace (1) or (2); and if DCT proponents choose to embrace (1) or (2), there is a further question of whether they can avoid the problems raised in the discussion of those possibilities.

Fourth, even if the proving-too-much reply shows us that the objection fails, it does not tell us why the objection fails. This makes the provingtoo-much reply rather weak and unsatisfactory. If the prior obligations objection really proves too much, it should be possible to identify the error in the objection rather than to stop after saying that the objection must have an error somewhere. Because of these criticisms, the proving-toomuch reply does not seem satisfactory to me.

Before proceeding further to a second reply to the prior obligations objection, it would be helpful to make a distinction between what Murphy calls metaethical DCT and normative DCT. ${ }^{20}$ Normative DCT (N-DCT) affirms (2). On N-DCT, there is a prior obligation which holds even if God does not command anything. N-DCT further states that all other moral obligations (aside from the prior obligation) obtain in virtue of this prior obligation and God's commanding activity. For example, there is a moral obligation not to murder because (i) God commanded us not to murder, and (ii) we have a moral obligation to obey God's commands. In contrast, the metaethical DCT (M-DCT) affirms (1). There is no prior moral obligation to obey God's commands. Instead, "all moral requirements are produced by God out of normative nothingness." ${ }^{21}$ So there is a moral obligation not to murder simply because God commanded us not to murder, without appeal to some prior moral obligation to obey God. On this view, we have no moral obligations prior to God's commanding activity.

With this distinction in mind, we can look at a second reply. The second reply is to just agree with critics that DCT requires (2) and affirm N-DCT. Evans, for example, claims that if the prior obligations objection is successful, DCT proponents "could still hold that the vast majority of our moral obligations are generated from or identical with divine

${ }^{19}$ See Mackie, The Miracle of Theism, 114-115; Mackie, Ethics.

${ }^{20}$ Murphy, "Divine Command, Divine Will, and Moral Obligation," 12.

${ }^{21}$ Murphy, "Divine Command, Divine Will, and Moral Obligation," 11. 
commands." ${ }^{22}$ Evans thinks that if the objection is successful, then one can just affirm N-DCT instead. John Hare, who is a proponent of N-DCT, says, "Divine commands do not generate all our obligations, because there is one important exception, namely the very obligation to obey Divine commands." ${ }^{23}$ Hare thinks that this is not a troubling exception since it is a necessary truth that God ought to be obeyed. ${ }^{24}$ To note, the prior obligation is not a brute fact on Hare's view, though it is a necessary truth. Hare's argument for this is that God is supremely good and what is supremely good is to be loved. To love God however, one must obey God. While one support for this is found in Scripture, Hare also provides a Kantian line of argument. He argues that to love God, we must share in God's ends, and this includes willing what God wills for our willing, which just is obedience. ${ }^{25}$ So the prior obligation is a necessary truth though not brute.

$\mathrm{N}$-DCT, however, seems problematic to me for a two main reasons. First, it seems that N-DCT would need to posit some moral obligation as a brute fact. As noted above, a critic might think that this is because DCT proponents must say that the prior obligation is a brute fact. But on Hare's view, the prior obligation is not a brute fact, though it is a necessary truth. N-DCT proponents may take a similar strategy as Hare and deny that the prior obligation is a brute fact. Still, it seems that Hare's view would still result in positing some other moral obligation as brute. We can simply ask Hare, is there a moral obligation to love what is supremely good? Is there an explanation why this is so? I suspect Hare would probably say that there is no further explanation, and it is a brute fact that we have a moral obligation to love what is supremely good. So, N-DCT proponents either have to hold that the prior obligation is a brute fact or appeal to a further explanation that ends up at another brute fact. By appealing to such brute facts, N-DCT would lose one of its explanatory advantages over non-theistic accounts of morality (like Wielenberg's ethical theory) since both theories posit brute moral obligations.

Second, the more major problem with N-DCT is that it is hard to justify. Why are all moral obligations, other than the prior obligation, grounded in God's commands? Proponents of N-DCT cannot use many of the standard arguments for DCT. For example, one strength of DCT in my view is that it fulfills the intuition that normative laws require a lawgiver. Others have expressed this intuition in other ways such as saying that "requirements require a requirer" or "obligations require an obligator." Many have argued that to fulfill this intuition, a moral lawgiver like God is necessary to explain the existence of moral obligations (or that God best explains the existence of moral obligations). This can be seen in some moral arguments for theism. However, the N-DCT proponent must accept that God's

\footnotetext{
${ }^{22}$ Evans, God and Moral Obligation, 101.

${ }^{23}$ Hare, God's Commands, 17-18.

${ }^{24}$ Hare, God's Commands, 18.

${ }^{25}$ Hare, God's Commands, 18.
} 
commands are not necessary to explain our moral obligations. After all, the prior obligation is a moral obligation which is not explained by God's commands. So, this undermines the claim that all normative laws require a lawgiver. If so, it seems hard to justify that all moral obligations, other than the prior obligation, are indeed grounded in God's commands. What reasons can one have for doing so? Furthermore, since the N-DCT proponent must concede that there is a brute moral obligation which does not require God as an explanation, we can ask the N-DCT proponent why all other moral obligations cannot also be brute. If the prior obligation, or its explanation, is a brute moral obligation, why must one appeal to God's commands to ground other moral obligations? N-DCT is hence problematic and should not be accepted by DCT proponents.

\section{Metaethical Divine Command Theory}

In the previous section, I offered two reasons why DCT proponents should not accept N-DCT. Now, I will offer reasons for DCT proponents to accept M-DCT. ${ }^{26}$ I will also argue that M-DCT can address the why-obey-God objection that seemed to make holding to (1) problematic. So M-DCT escapes the prior obligations objection.

First, in arguing for DCT, a powerful motivation for DCT is the social nature of obligations. ${ }^{27}$ Obligations have a social nature in the sense that they arise by one person obligating another person. As noted, this has been expressed in various ways such as the idea that obligations require an obligator. Others have also provided further arguments for the social nature of moral obligations. Robert Adams, for example, argues for the social nature of moral obligations based on the fact that we feel guilty about violating our moral obligations. ${ }^{28}$ The prior obligation however would lack this social nature. After all, if the prior obligation exists, who obligates us to obey God? If we propose that a higher being obligates us to obey God, we can ask once again why we should obey that being and the same problem will arise ad infinitum. It seems then that one should say no one obligates us to obey God. If no one obligates us to obey God, then the prior obligation lacks the social nature. Hence, DCT proponents should not be committed to the existence of a prior obligation. Since M-DCT does not admit the existence of a prior obligation and on M-DCT all moral obligations have the social nature, DCT proponents should embrace M-DCT.

Second, some versions of DCT entail M-DCT. The versions I have in mind are those that take our moral obligations to be identical to God's commands. ${ }^{29}$ On such versions, God's commands and our moral obligations

\footnotetext{
${ }^{26}$ See Murphy for a different set of arguments. Murphy notes that arguments from the divine attributes (divine sovereignty, omnipotence, liberty and impeccability) have been offered in favor of a metaethical version of theistic ethical theories ("Divine Command, Divine Will, and Moral Obligation," 12-16).

${ }^{27} \mathrm{See}$, for example, Adams, Finite and Infinite Goods.

${ }^{28}$ Adams, Finite and Infinite Goods, 238-241.

${ }^{29} \mathrm{See}$, for example, Adams, Finite and Infinite Goods.
} 
are one and the same thing. Now, suppose someone asks, "Why ought I do what is right?" A plausible reply is "simply because it is right." We don't think that there needs to be a moral obligation to follow our moral obligations. It does not make much sense to reply "because it is right to do what is right" or "because there is a moral obligation to fulfill our moral obligations." Since there is no moral obligation to fulfill our moral obligations, and this version of DCT takes it that our moral obligations are identical to God's commands, then it follows that there is no moral obligation to obey God's commands. So versions of DCT that take our moral obligations to be identical to God's commands entail M-DCT. On these versions, M-DCT can also meet the why-obey-God problem. When someone asks, "Why ought I do what God's commands," one does not need to say, "because there is a moral obligation to do what God's commands." Instead one can reply, "because God's commands are our moral obligations. They are the same thing." On M-DCT, the question "why ought I do what God commands" just is the question "why ought I fulfill my moral obligations."

Third, consider legal obligations. Philosophers may disagree on what justifies legal authority. However, it seems clear that if legal authority can be justified, then the appropriate legal authorities can create genuine legal obligations (typically by instituting laws or issuing commands) for those under its authority. Similar to the structure of DCT then, we can say that if an appropriate legal authority commands $X$, then $X$ is a legal obligation for those under the legal authority. Call this view legal authority command theory (LACT). Now suppose one raised the prior obligations objection in the case of legal obligations. The objector says that either:

(1a) There is no legal obligation to do what legal authorities command, or

(2a) There is a legal obligation to do what legal authorities command.

As in the case of DCT, the objector then says (1a) is implausible because, without a prior legal obligation to obey legal authorities, the laws instituted by legal authorities cannot create legal obligations for us. However, if one accepts (2a), then this prior legal obligation must exist independent of the commands of legal authorities. Either way then, legal obligations cannot be grounded in legal authorities.

I think it is easy for those who hold to LACT to reject (2a). Defenders of LACT can simply ask how legal obligations can exist independent of the commands of legal authorities. Legal obligations must be grounded in legal authorities. Suppose there were no legal authorities on earth. One who affirms (2a) would have to say that there exists a legal obligation, namely the prior legal obligation. This seems deeply unintuitive. In the absence of any legal authorities (and them passing laws), it seems that there are no legal obligations at all. Therefore, one who holds to LACT should reject (2a). In reply to the objector, defenders of LACT can embrace (1a) and argue that (1a) does not entail that the laws instituted by legal 
authorities cannot create legal obligations for us. One can instead appeal to the grounding of legal authority. Whatever grounds legal authority does not create a legal obligation to obey legal authorities. Instead, whatever grounds legal authority gives legal authorities the power to create legal obligations. Similarly, a DCT proponent may reject (2) and accept (1) on the same grounds. If moral obligations come from God, then DCT proponents should not think that there is a prior moral obligation to obey God. To address the why-obey-God problem, DCT proponents can similarly appeal to whatever grounds God's moral authority. Whatever grounds God's moral authority does not create a moral obligation to obey God. Instead, whatever grounds God's moral authority gives God the power to create moral obligations. Hence, DCT proponents should embrace M-DCT, and this is not problematic.

\section{Objection: But We Ought to Obey God!}

Theists who want to affirm that we ought to obey God may object to $\mathrm{M}-\mathrm{DCT}$, complaining that M-DCT entails that it is not the case that we ought to obey God. I believe there are at least three strategies that a proponent of M-DCT can take. First, one might notice that "we ought to obey God" can be understood de dicto or de re. Under the de dicto reading, "we ought to do what God commands" means that there is a moral obligation to do what God commands. Under the de re reading, "we ought to do what God commands" just means that for each act that God has commanded, we have a moral obligation to do that act. For example, God has commanded us to do acts like loving one another, upholding justice, and honoring one's parents. Since we have moral obligations to do these acts, we have a moral obligation to do what God has commanded in the de re sense. So M-DCT can affirm that we ought to obey God if understood de re.

A second strategy for M-DCT proponents is to accommodate the idea that we ought to obey God in a different sense. Many times, people say statements like "you ought to do what is right" or "you should fulfill your moral duties." These statements seem natural just as theists say "you ought to obey God." Evans, however, points out that when a person says "you ought to fulfill your moral duties," they do not mean "you have a moral duty to fulfill your moral duties." ${ }^{30}$ Instead, saying that one ought to fulfill his moral obligations is just saying that "those obligations have genuine authority." ${ }^{\prime 31}$ Likewise, saying one ought to obey God's commands is just saying that God's commands have genuine moral authority. ${ }^{32}$ Another way of putting it is to consider my earlier example of legal obligations again. When one says that we ought to obey legal authorities, we do not mean that there is a legal obligation to obey legal authorities. Saying that we ought to obey legal authorities just means that legal authorities can

\footnotetext{
${ }^{30}$ Evans, God and Moral Obligation, 100.

${ }^{31}$ Evans, God and Moral Obligation, 100.

${ }^{32}$ Evans, God and Moral Obligation, 100.
} 
create legal obligations for us. They have genuine authority. Similarly, when we say that we ought to obey God, we do not need to mean that there is a moral obligation to obey God. Instead, we can say that we ought to obey God in the sense that God can create our moral obligations as God has genuine moral authority.

Third, a proponent of M-DCT might say that M-DCT entails that God can create all sorts of obligations and this include obligations to obey God. ${ }^{33}$ If God commands you to do an act, you merely have an obligation to do that act. However, if God commands you to do an act because He commanded it, then you have an obligation to do $\mathrm{X}$ because He commanded $i t$. This latter obligation would count as an obligation to obey God. This is because to obey God is to do something because God commanded you to do so. Therefore, on M-DCT, there can be a moral obligation to obey God, namely, whenever God commands us to do certain acts because He commanded it. Let me use an analogy to illustrate this point. If a legal authority makes a rule to do $X$, then you have a legal obligation to do $X$. Here, there is no legal obligation to obey legal authorities. The legal authority can instead make it a rule to do X because they told you so. This would then result in a legal obligation to do $X$ because the legal authority told you so. Doing $X$ because the legal authority told you so is what it is to obey the legal authorities. So, in cases where the legal authorities make it a rule to do $\mathrm{X}$ because they told you so, you would then have an obligation to obey legal authorities. In this way, M-DCT can explain how there can be obligations to obey God.

\section{Objection: Brute Ethical Facts}

One might object that I had criticized N-DCT for positing brute ethical facts. One might think that M-DCT also posits brute ethical facts. M-DCT says that God creates our moral obligations out of normative nothingness. This cries out for an explanation. It seems natural to ask, how can God do this? If there is no moral obligation to obey God's commands, how can his commanding activity create our moral obligations? Now, if there is no further explanation why this is so, then M-DCT seems to stop at an unsatisfactory explanatory point. Also, M-DCT would suffer similar criticisms as N-DCT above.

But M-DCT can offer a further explanation. Consider once again the case of legal obligations. As argued earlier, defenders of LACT can affirm that whatever grounds legal authority would give legal authorities the power to create legal obligations. The same explanation can be given by DCT proponents. Indeed, DCT proponents have tried to ground God's moral authority in various ways such as by appealing to God's character, God's position to us, and God's desires towards us. For example, David Baggett and Jerry Walls argue that God's perfect knowledge, love, and

${ }^{33}$ I thank Mark Murphy for this point. 
power jointly gives God the moral authority to issue binding commands. ${ }^{34}$ Therefore, M-DCT does not stop at an unsatisfactory explanatory point. The explanation is that God has moral-authority-granting-properties.

Here, one might object that all of the existing accounts of what grounds God's authority are not adequate and so this would pose a problem for M-DCT. This objection however will not work. Even if current accounts of what grounds God's authority fail, M-DCT proponents can still hold that whatever grounds God's moral authority explains why God has the power to create moral obligations for us. Just as a defender of LACT does not need to have worked out a satisfactory theory of legal authority in order to hold to LACT, the M-DCT proponent does not need to have worked out a satisfactory theory of God's moral authority in order to hold to M-DCT.

Now the objector might say that, even if there is an explanation for why God can create our moral obligations out of normative nothingness, we can further ask why it is the case that if a being with moral-authority-granting-properties commands us to $p$, then we have a moral obligation to $p$. What grounds this fact? The objector can point out that even if there is a further explanation, the explanatory chain has to stop somewhere and so there will be a brute ethical fact. Indeed, Heathwood has given a convincing argument that all moral theories must posit at least one brute ethical fact. ${ }^{35}$

I admit that I think it is a brute fact that if a being with moral-authority-granting-properties commands us to $p$, then we have a moral obligation to $p$. This seems like an adequate explanatory stopping point. Even if I'm wrong and there is a further explanation, it seems right to think that the explanatory chain has to stop somewhere and so there will be a brute fact somewhere along the line. Admitting all of this, however, does not pose a problem for M-DCT. First, it seems to me that the brute fact above is not an ethical fact. This is because it is a conditional which does not entail the existence of any moral obligations or any normative state of affairs. So, M-DCT need not posit any brute ethical facts. Second, even if the conditional above is to be considered as a brute ethical fact, this is not problematic because it is not a brute moral obligation. My criticism of N-DCT was not that it posited brute ethical facts; rather the problem with N-DCT was that it posited a brute moral obligation. On M-DCT, however, none of our moral obligations are brute since all of our moral obligations are explained by God's commands. The conditional above is not a moral obligation. Therefore, M-DCT can avoid the earlier problems I raised with N-DCT. Unlike $\mathrm{N}$-DCT, M-DCT would have an explanatory advantage over non-theistic accounts of morality (like Wielenberg's ethical theory), since M-DCT does not posit any brute moral obligations but offers a deeper explanation for all our moral obligations. Also, since M-DCT does not posit any brute moral obligations, it can also use the standard arguments for DCT unlike

\footnotetext{
${ }^{34}$ Baggett and Walls, Good God, 122-123.

${ }^{35}$ Heathwood, "Could Morality Have a Source?"
} 
N-DCT. Lastly, it would not be an objection to M-DCT to point out that it posits other kinds of brute ethical facts which are not moral obligations. This is because M-DCT is a theory of our moral obligations. All M-DCT is trying to explain is the grounds of our moral obligations, not the grounds of all ethical facts. So, as long as the brute ethical fact it posits is an adequate explanatory stopping point, then this would not be problematic for M-DCT.

\section{Conclusion}

I have argued that DCT proponents should affirm M-DCT. Doing so escapes the prior obligations objection. Other theological stateist theories can also modify their theories accordingly to escape the prior obligations objection. For example, take Matthew Jordan's Divine Attitude Theory (DAT) which says that our moral obligations are grounded in God's attitudes. ${ }^{36}$ One may raise the prior obligations objection and ask if there is a moral obligation to do what God is pleased with and to not do what God is displeased with. Jordan can simply adopt metaethical DAT and say that there is no prior moral obligation to do what God is pleased with. Instead, God's attitudes ground our moral obligations out of normative nothingness. So, the same defenses as above could easily be adopted by switching commands to attitudes. The prior obligations objection is, I believe, unsuccessful against theological stateism. ${ }^{37}$

Nanyang Technological University

\section{References}

Adams, Robert Merrihew. 1999. Finite and Infinite Goods: A Framework for Ethics (Oxford University Press).

Baggett, David, and Jerry L. Walls. 2011. Good God: The Theistic Foundations of Morality (Oxford University Press). https://doi.org/10.1093/acprof:oso/9780199751808.001.0001

Cudworth, Ralph. 1996. A Treatise Concerning Eternal and Immutable Morality. Edited by Sarah Hutton (Cambridge University Press).

Evans, C. Stephen. 2013. God and Moral Obligation (Oxford University Press). https://doi.org/10.1093/acprof:oso/9780199696680.001.0001

Fales, Evan. 2010. “Divine Commands and Moral Obligation." Philo 13: 151-166. https://doi.org/10.5840/philo20101323

\footnotetext{
${ }^{36}$ Jordan, "Divine Commands or Divine Attitudes."

${ }^{37}$ I wish to acknowledge the funding support for this project from Nanyang Technological University under the Undergraduate Research Experience on CAmpus (URECA) programme. For suggestions and comments, I like to thank Esther Goh, Preston Greene, Andrew Forcehimes, Mark Murphy, Lemuel Tang, David Graieg, Wayne Riggs, Ata Akhlaghi, Lance Hannestad, Ben Bavar, Perry Hendricks, the participants at the 2019 University of Oklahoma Graduate Philosophy Conference, and the two anonymous reviewers of this journal.
} 
Flannagan, Matthew, and Paul Copan. 2014. Did God Really Command Genocide?: Coming to Terms with the Justice of God (Baker Books).

Forcehimes, Andrew. 2017. “Ethical Theories and Their Application." In Exploring Moral Problems: An Introductory Anthology, edited by Steven M. Cahn and Andrew Forcehimes (Oxford University Press), 2-48.

Hare, John E. 2015. God's Command (Oxford University Press). https://doi.org/10.1093/acprof:oso/9780199602018.001.0001

Heathwood, Chris. 2012. "Could Morality have a Source?" Journal of Ethics and Social Philosophy 6: 1-19. doi: https://doi.org/10.26556/jesp.v6i2.62

Jordan, Matthew Carey. 2013. "Divine Commands or Divine Attitudes?" Faith and Philosophy 30: 159-170. doi.org/10.5840/faithphil201330212

Mackie, J. L. 1977. Ethics: Inventing Right and Wrong (Penguin).

Mackie, J. L. 1983. The Miracle of Theism (Oxford University Press).

Miller, Christian B. 2009. "Divine Desire Theory and Obligation." In New Waves in Philosophy of Religion, edited by Yujin Nagasawa and Erik J. Wielenberg (Palgrave Macmillan), 105-124.

Murphy, Mark C. 1998. "Divine Command, Divine Will, and Moral Obligation." Faith and Philosophy 15: 3-27. https://doi.org/10.5840/faithphil19981512

Quinn, Philip L. 2002. “Obligation, Divine Commands and Abraham's Dilemma." Philosophy and Phenomenological Research 62: 459-466.

https://doi.org/10.1111/j.1933-1592.2002.tb00018.x

Schroeder, Mark. 2005. "Cudworth and Normative Explanations." Journal of Ethics and Social Philosophy 1: 1-27. https://doi.org/10.26556/jesp.v1i3.15

Wielenberg, Erik J. 2014. Robust Ethics: The Metaphysics and Epistemology of Godless Normative Realism (Oxford University Press). https://doi.org/10.1093/acprof:oso/9780198714323.001.0001

Wolterstorff, Nicholas. 2008. Justice: Rights and Wrongs (Princeton University Press). https://doi.org/10.1515/9781400828715 